\title{
Multi-scale evaluations of submarine groundwater discharge
}

\author{
MAKOTO TANIGUCHI ${ }^{1}$, MASAHIKO ONO ${ }^{2} \boldsymbol{\&}$ MASAHIRO TAKAHASHI ${ }^{3}$ \\ 1 Research Institute for Humanity and Nature, 457-4 Kamigamo, Kita-ku, Kyoto 603-8047, Japan \\ makoto@chikyu.ac.jp \\ 2 Agency of Industrial Science and Technology, 1-1-1 Azuma, Tsukuba, Ibaraki 305-8567, Japan \\ 3 Nippon Koei Co., Ltd, 2304 Inanihara, Tsukuba, Ibaraki 300-1259, Japan
}

\begin{abstract}
Multi-scale evaluations of submarine groundwater discharge (SGD) have been made in Saijo, Ehime Prefecture, Shikoku Island, Japan, by using seepage meters for point scale, ${ }^{222} \mathrm{Rn}$ tracer for point and coastal scales, and a numerical groundwater model (SEAWAT) for coastal and basin scales. Daily basis temporal changes in SGD are evaluated by continuous seepage meter and ${ }^{222} \mathrm{Rn}$ mooring measurements, and depend on sea level changes. Spatial evaluations of SGD were also made by ${ }^{222} \mathrm{Rn}$ along the coast in July 2010 and November 2011. The area with larger ${ }^{222} \mathrm{Rn}$ concentration during both seasons agreed well with the area with larger SGD calculated by 3D groundwater numerical simulations.
\end{abstract}

Key words submarine groundwater discharge; coastal zone; radon; numerical groundwater model; seepage meter

\section{INTRODUCTION}

Submarine groundwater discharge (SGD) is one of the important pathways of water and dissolved material loads from the land to the ocean (Church 1996, Moore 1996, Taniguchi et al. 2002, Burnett et al. 2006, Moore, 2010). In the last couple of decades, the distribution of SGD and fluxes of freshwater and nutrients through SGD were observed in situ at many locations at point scales. Seepage meters, which can measure SGD directly, are used widely to evaluate spatial and temporal changes of SGD (Taniguchi et al. 2005, 2006a,b). Radon $\left({ }^{222} \mathrm{Rn}\right)$, which is usually $2-3$ orders of magnitude higher in groundwater than in surface waters, is a useful tracer of groundwater inputs into the oceans (Burnett et al. 2001, Dulaiova et al. 2005, Dimova et al. 2009, Kim et al. $2003,2005,2011)$ at coastal scales. The methodology of continuous measurement of SGD by automated seepage meters and ${ }^{222} \mathrm{Rn}$ monitoring surveys has been developed in the last decade. The methods using ${ }^{222} \mathrm{Rn}$ have been successfully applied in 10 - to $100-\mathrm{km}$ scale study areas. For evaluations of SGD by numerical simulations, density-driven fluid flow models have been employed on a coastal scale by Robinson et al. (2006) and on a basin scale by SEAWAT (Langevin et al. 2007). In the present study, we compare SGD values, which are derived from different scales with different methodologies in the Saijo area of Ehime Prefecture, Japan, where three different methods have been used, i.e. seepage meters for the point scale, ${ }^{222} \mathrm{Rn}$ for the coastal scale, and numerical groundwater simulation for the basin scale.

\section{STUDY AREA AND IN SITU METHODS}

Figure 1 shows the location of the study area, Saijo in Ehime Prefecture, Shikoku Island, Japan, which faces the Seto-uchi Inland Sea. Saijo city is located between 33.85 to $33.99^{\circ} \mathrm{N}$ and 133.00 to $133.26^{\circ} \mathrm{E}$. The whole area is divided into two plains: the eastern Saijo plain and the western Shuso plain. Each plain is composed of sediments of Pliocene to Quaternary age. The southern boundary of the area is Mount Ishizuchi (1982 m a.s.1.), the highest peak in western Japan. Spring water discharges around the end of alluvial fans, and the groundwater occurs in sandy Pliocene sediments and forms extensive unconfined to leaky-confined aquifers, i.e. the area has both confined and unconfined aquifers. There is an artesian water zone in the central part of the Saijo plain (Kumar et al. 2012).

\section{Seepage meter measurements}

Automated seepage meters (Taniguchi and Iwakawa 2001) were employed to observe continuous SGD rate at site A (Koubousui) and site B (Kawarazu). The measurements were made every 10 minutes during 14-24 July 2010. Seepage meters are made from vented benthic chambers with 


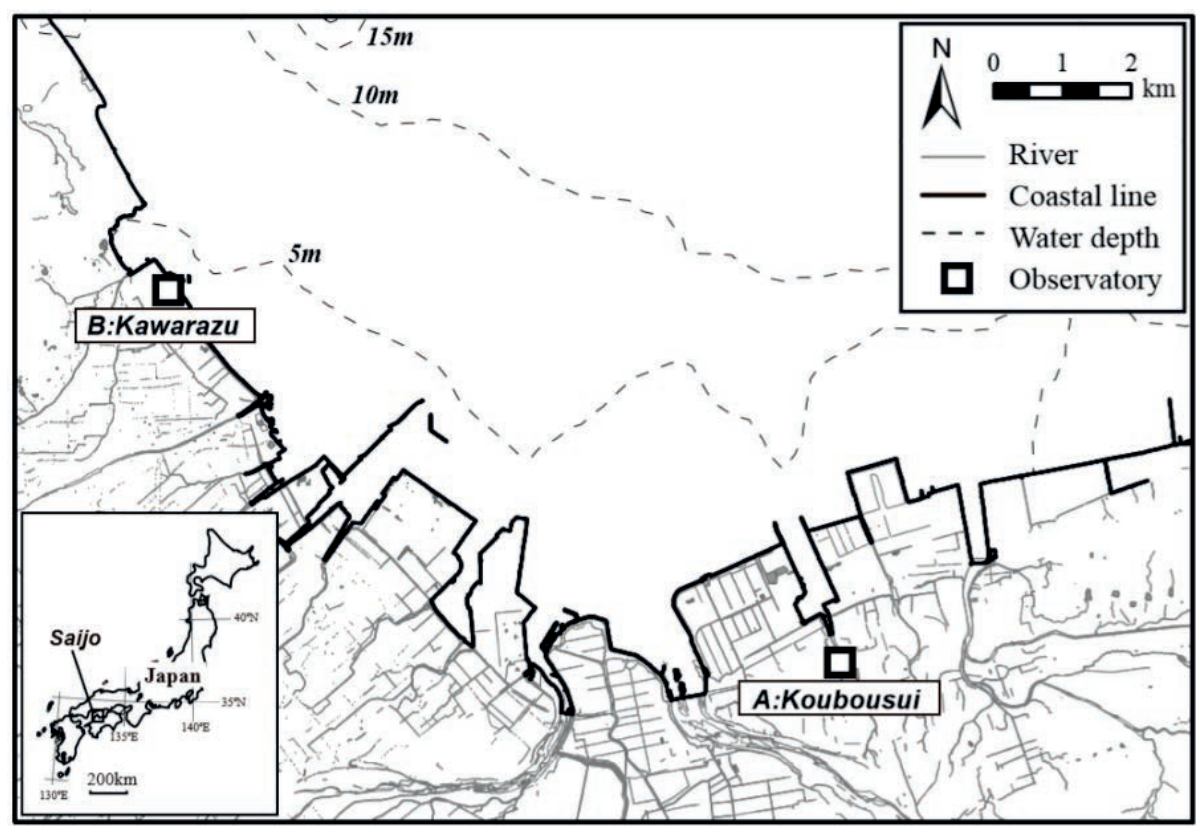

Fig. 1 Location of study area with sites A and B.

some type of flux measurement device, and are the only means available to evaluate SGD fluxes directly. We used the "continuous heat type" automated seepage meters to make the measurements in this study. Flux measurements are made by assessing a temperature gradient in water flowing between two in-line sensors in a tube with a heating element at one end. When there is no water flow, the temperature difference between the sensors is highest and it decreases systematically with increasing flow velocity. The chambers were made from the top or bottom sections of the drums, with a collection area of $0.255 \mathrm{~m}^{2}$.

\section{Rn measurements}

The continuous ${ }^{222} \mathrm{Rn}$ monitoring and water sampling surveys in Saijo area were conducted during 14-24 July 2010 and 17-22 November 2011. The ${ }^{222} \mathrm{Rn}$ activities with a half-life of 3.8 days in water were measured using portable continuous Rn-in-air monitors (Rad7: Durridge Company) interfaced with an air-water exchanger. Properties of this equipment and the principles of ${ }^{222} \mathrm{Rn}$ measurements are described in detail in Burnett et al. (2001). The activities of ${ }^{222} \mathrm{Rn}$ in seawater were measured continuously for each Rn field survey, using a boat along the coast, tracking close to the coast $(\sim 50 \mathrm{~m}$ from the coastline at a water depth of about $2-5 \mathrm{~m})$. Coastal springs, groundwater and river waters were also sampled for ${ }^{222} \mathrm{Rn}$. The ${ }^{222} \mathrm{Rn}$ concentrations were measured with a single Rad7 monitor with a Rad-Aqua accessory.

The depth of water sampling was $0.5 \mathrm{~m}$, the pumping rate was $5-10 \mathrm{~L} \mathrm{~min}^{-1}$ and the measurement intervals were $10 \mathrm{~min}$. In order to compare Rn with the SGD flux measured by seepage meters, we set up one mooring in the small embayment of Kawarazu (site B in Fig. 1). Another mooring was deployed at Koubousui (site A in Fig. 1). For these mooring stations, we measured ${ }^{222} \mathrm{Rn}$ concentrations using a single $\operatorname{Rad} 7$ monitor and water level by using an Onset Water Level Sensor for each site using the same method as Burnett et al. (2001). We also monitored ${ }^{222} \mathrm{Rn}$ concentrations in the air during the same period using another Rad7 monitor.

\section{TEMPORAL CHANGES IN SGD}

Continuous measurements of SGD have been made by automated seepage meters at site A (Koubousui) and site B (Kawarazu) from 14-21 July 2010 every 10 minutes. Conductivity meters and thermometers were installed inside the chamber of the seepage meters for 10 minute interval measurements. Sea level is also recorded every 10 minutes. Figure 2 shows the results for site B 


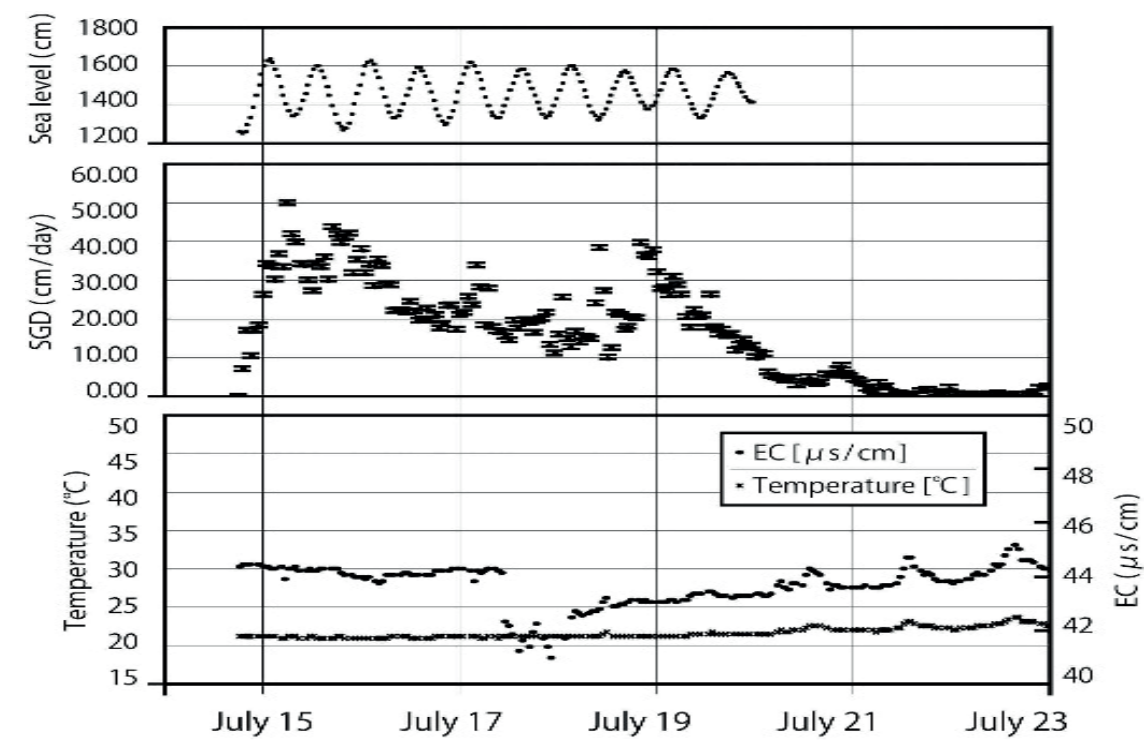

Fig. 2 Temporal changes in sea level, SGD, temperature and electrical conductivity (EC) at Kawarazu.

(Kawarazu). As can be seen from Fig. 2, SGD measured by seepage meter increases with decreasing sea level. Lower temperature and electrical conductivity (EC) in the chamber of the seepage meter corresponds to the higher SGD observed by the seepage meter, which indicates considerable fresh groundwater discharge during low tide. The average of SGD during 15-19 July 2010 was about $22 \mathrm{~cm} /$ day, and during 20-23 July 2010 is about $3 \mathrm{~cm} /$ day. Temperature and electrical conductivity of SGD also increased during 15-23 July 2010 corresponding to the increase of fresh SGD.

Changes of ${ }^{222} \mathrm{Rn}$ and sea level at both sites A and B are shown in Figs 3 and 4. As can be seen from Fig. 3, ${ }^{222} \mathrm{Rn}$ at Kawarazu (site B) is clearly anti-correlated with the sea level. The ${ }^{222} \mathrm{Rn}$ is an indicator of the magnitude of SGD, and reveals that SGD increases with decreasing sea level, although the relationship between see level and SGD is not clear at location A (Koubousui).

\section{SPATIAL CHANGES IN SGD}

To evaluate the spatial SGD distribution along the coast in Saijo, ${ }^{222} \mathrm{Rn}$ surveys were conducted in July 2010 and November 2011. Figure 5 shows the distribution of ${ }^{222} \mathrm{Rn}$ in coastal sea water in July 2011. As can be seen in Fig. 5, larger ${ }^{222} \mathrm{Rn}$ concentrations are found north of Koubousui (site A), and southeast of Kawarazu (site B). A similar distribution pattern was also found in November 2011.

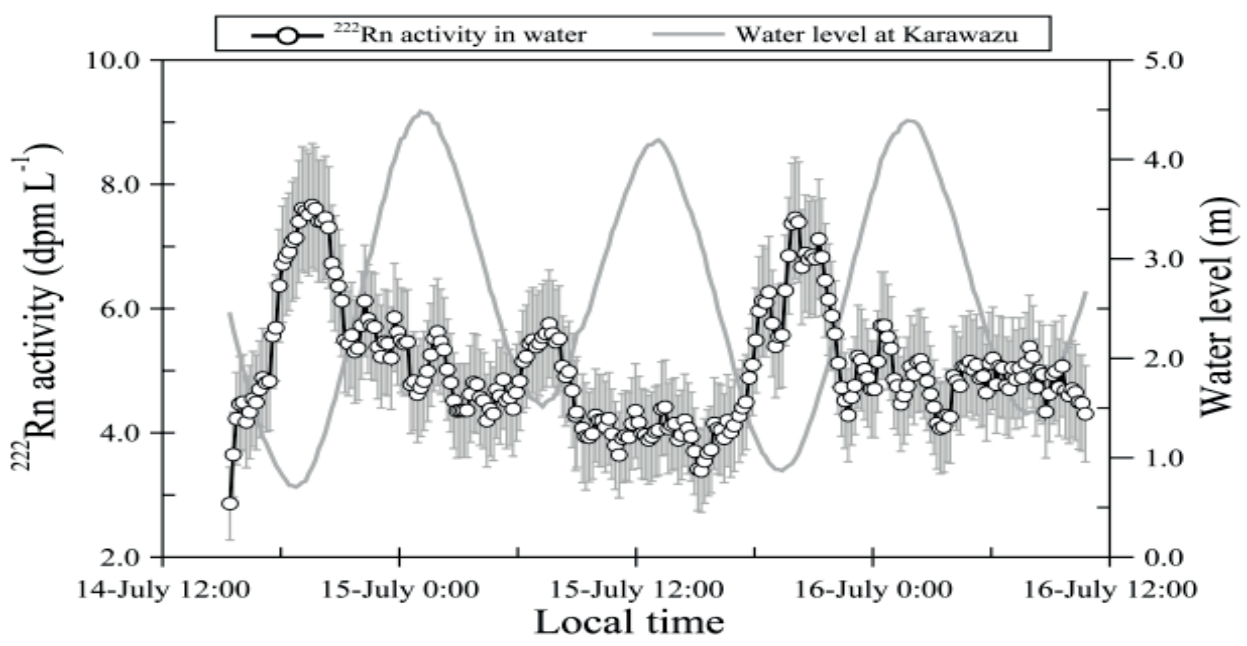

Fig. 3 Temporal changes in ${ }^{222} \mathrm{Rn}$ and sea level at Kawarazu. 


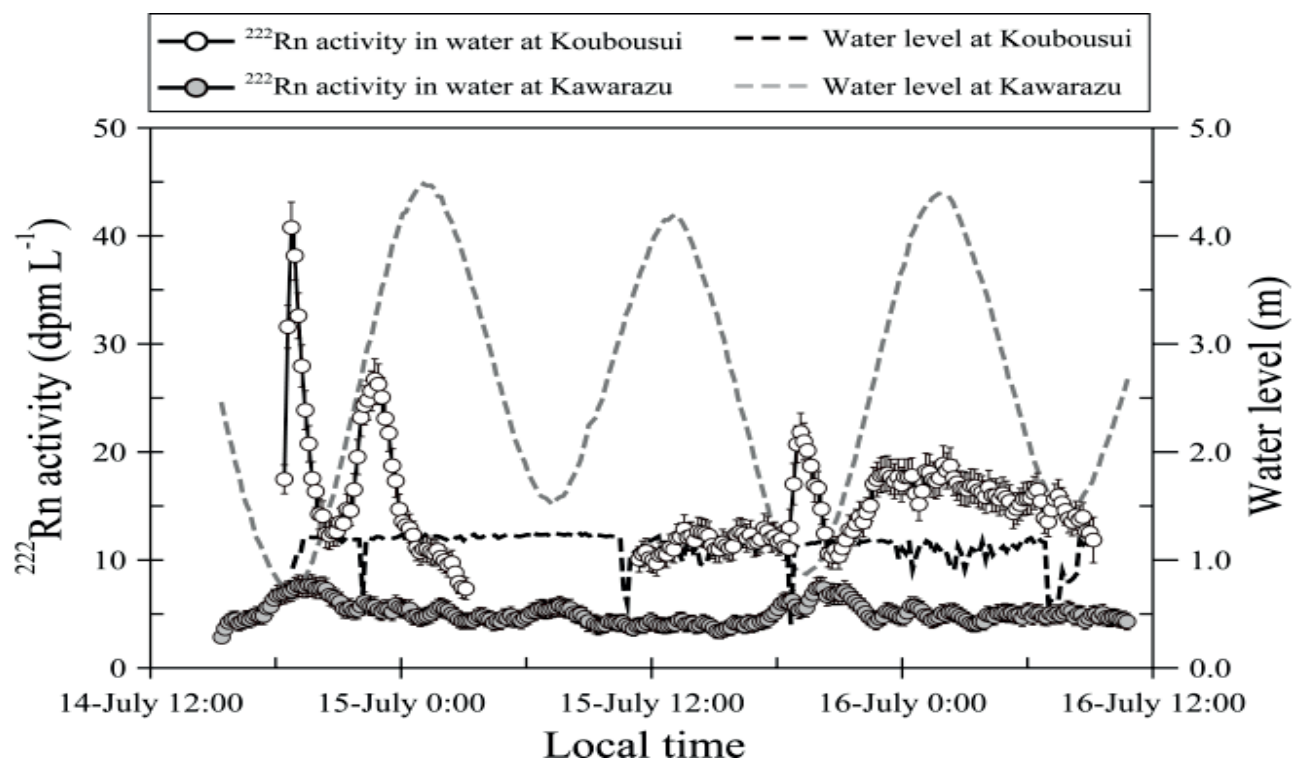

Fig. 4 Temporal changes in ${ }^{222} \mathrm{Rn}$ and sea level at Koubousui and Kawarazu.

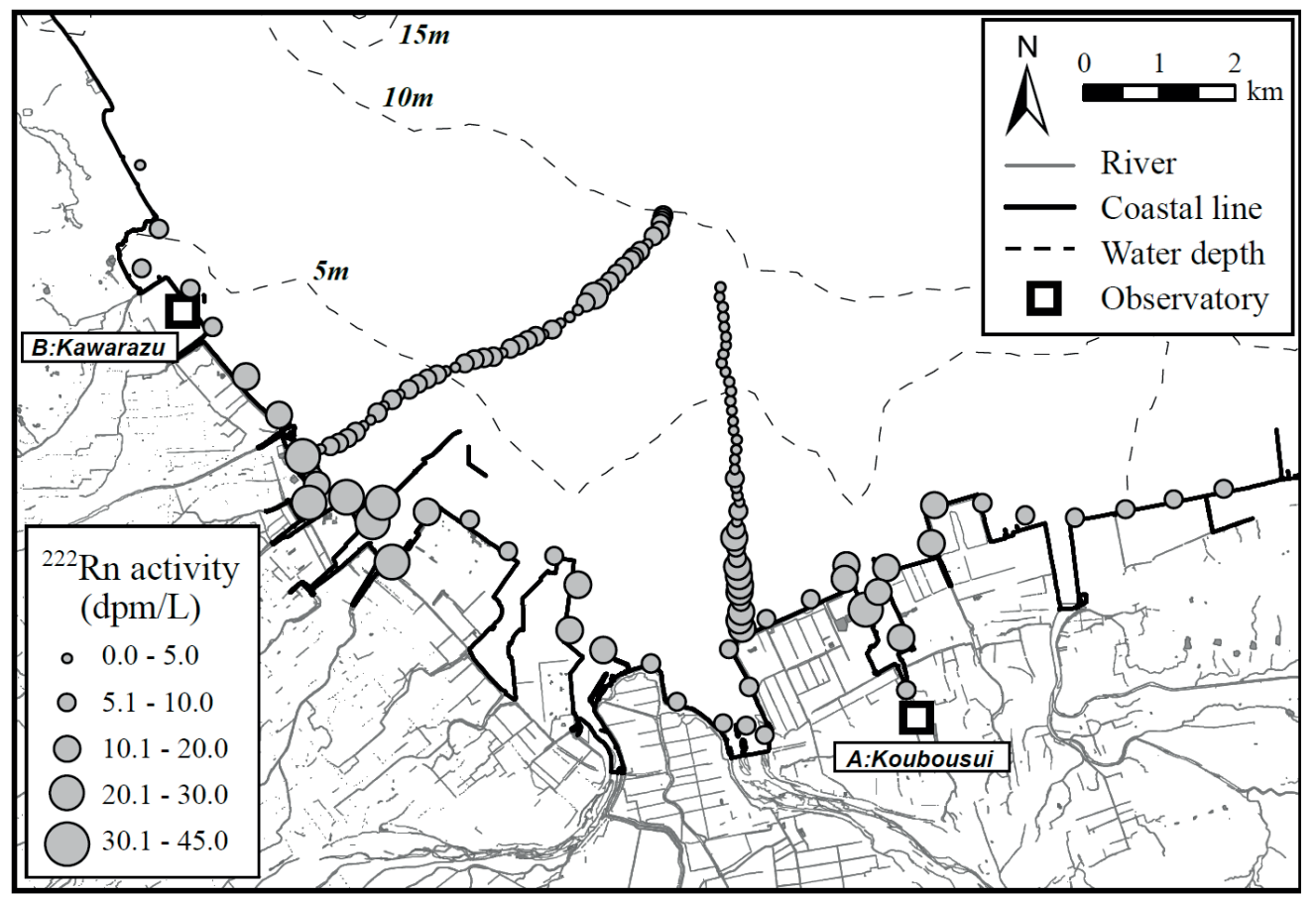

Fig. $5^{222}$ Rn distribution (dpm/L) in July 2011.

\section{COMPARISONS OF MODEL RESULTS WITH OBSERVED SGD}

To simulate SGD along the costal line in the Saijo area, a 3D numerical groundwater model was established using SEAWAT2000 Ver. 4 (Figs 5 and 6) with $\mathrm{X}=9250 \mathrm{~m}(125 \mathrm{~m} \times 74$ grids), $\mathrm{Y}=$ $8250 \mathrm{~m}$ (125 $\mathrm{m} \times 66$ grids) and $\mathrm{Z}=4$ layers (in total 19536 grids). Hydrogeological characteristics such as geological settings, soil types, permeabilities of reference and model are shown in Table 1.

Groundwater levels observed from 1 January 2007 to 31 December 2008 in 16 boreholes at Saijo plain were used to validate the numerical groundwater simulations. Adjustments of permeability in each grid of the 3D model were made to minimize the difference between observed and calculated groundwater levels each month (24 months). 


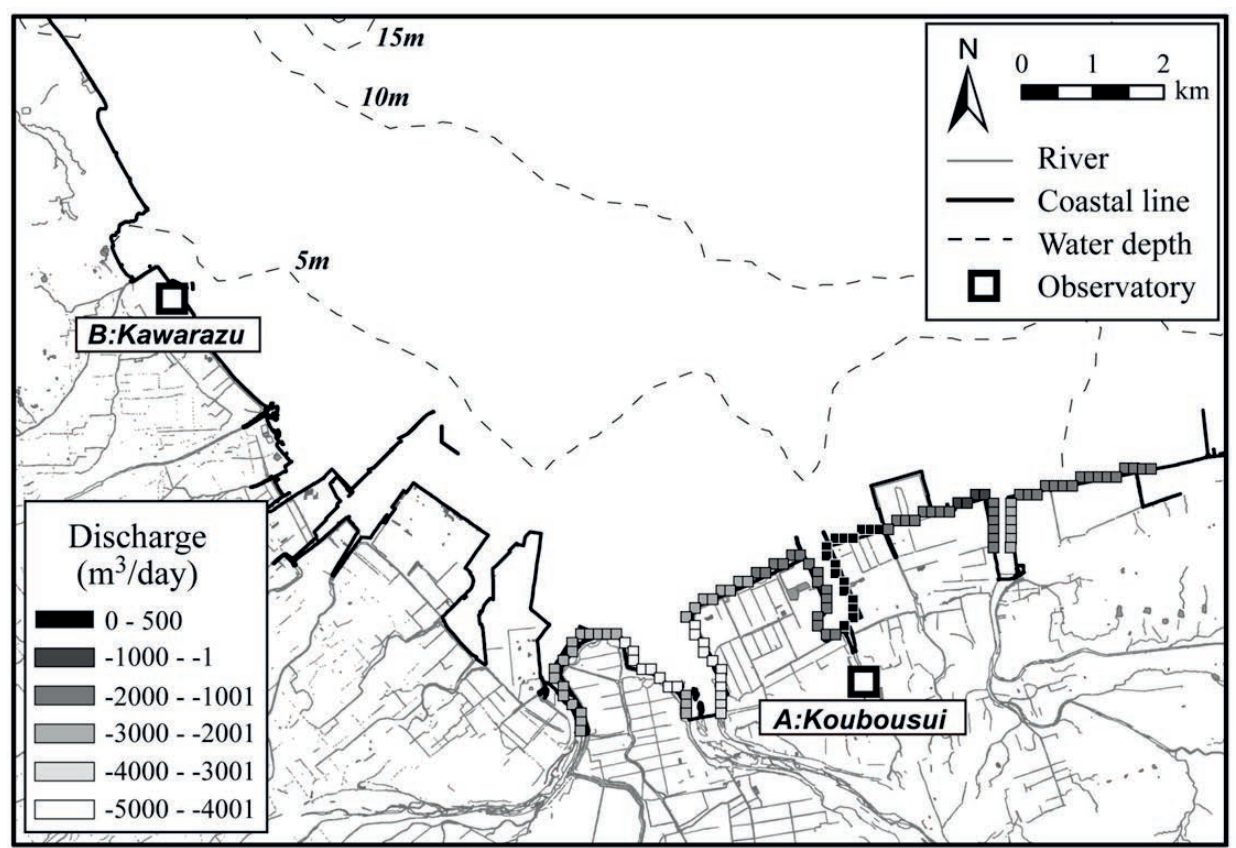

Fig. 6 Water exchange between land and ocean.

Table 1 Hydrogeological information used in the model.

\begin{tabular}{|c|c|c|c|c|c|}
\hline Layers & $\begin{array}{l}\text { Geological } \\
\text { setting }\end{array}$ & & Soil & $\begin{array}{l}\text { Permeability } \\
\text { (in reference) }\end{array}$ & $\begin{array}{l}\text { Permeability } \\
\text { (model) }\end{array}$ \\
\hline 1 & $\mathrm{~A} 1 \sim \mathrm{A} 2 \mathrm{~b}$ & A2 & $\begin{array}{l}\text { Sandy gravel, sand, } \\
\text { gravel }\end{array}$ & $\begin{array}{l}101 \mathrm{~cm} / \mathrm{sec} \sim \\
10^{-2} \mathrm{~cm} / \mathrm{sec}\end{array}$ & $\begin{array}{l}2.5 \times 100 \mathrm{~cm} / \mathrm{sec} \sim \\
1.0 \times 10^{-3} \mathrm{~cm} / \mathrm{sec}\end{array}$ \\
\hline 2 & $\mathrm{~A} 3 \sim \mathrm{Dtf}$ & A3 & $\begin{array}{l}\text { Sand, fine sand with } \\
\text { silt, clay }\end{array}$ & $\begin{array}{l}10^{-4} \mathrm{~cm} / \mathrm{sec} \sim \\
10^{-5} \mathrm{~cm} / \mathrm{sec}\end{array}$ & $\begin{array}{l}1.0 \times 10^{-5} \mathrm{~cm} / \mathrm{sec} \sim \\
5.0 \times 10^{-5} \mathrm{~cm} / \mathrm{sec}\end{array}$ \\
\hline 3 & $\mathrm{D} 2 \sim \mathrm{D} 4$ & D2 & Sandy gravel & $\begin{array}{l}100 \mathrm{~cm} / \mathrm{sec} \sim \\
10^{-3} \mathrm{~cm} / \mathrm{sec}\end{array}$ & $\begin{array}{l}2.5 \times 100 \mathrm{~cm} / \mathrm{sec} \sim \\
2.5 \times 10^{-2} \mathrm{~cm} / \mathrm{sec}\end{array}$ \\
\hline 4 & $<$ D5 & D5 & Silt, clay & unknown & $\begin{array}{l}7.5 \times 10^{-1} \mathrm{~cm} / \mathrm{sec} \sim \\
5 \times 10^{-3} \mathrm{~cm} / \mathrm{sec}\end{array}$ \\
\hline
\end{tabular}

Figure 6 shows the calculated SGD along the coast at the Saijo plain for July 2007 and July 2008. Negative values show saltwater intrusion and positive values show SGD. As can be seen from Fig. 6, saltwater intrusion can be found due to groundwater extraction for the paddy fields, in particular at locations near the west bay of Koubousui (light colour). The largest average of SGD are found at the east of the bay near Koubousui (dark colour) according to the 3D numerical model. This result agrees with the coastal-scale evaluations of higher SGD by higher ${ }^{222} \mathrm{Rn}$ (Fig. 5).

\section{CONCLUSIONS}

Multi-scale evaluations of SGD were made in Saijo, Ehime Prefecture, Japan. Local (point scale) continuous measurements of SGD by automated seepage meters and ${ }^{222} \mathrm{Rn}$ monitoring can reveal fast temporal changes in SGD, for example, due to changes of sea level. Spatial differences in SGD for coastal scales can be evaluated by ${ }^{222} \mathrm{Rn}$. Both methods are useful for evaluating temporal and spatial changes of SGD under hydrogeological and coastal oceanography processes. For basinscale evaluations of SGD, 3D numerical simulations of SGD can be used to model water exchange between land and ocean. The results can be compared with coastal scale evaluation of SGD by ${ }^{222} \mathrm{Rn}$. The three different methods are useful for different spatial scales (point, coastal and basin) and should be combined with each other for a better understanding of SGD. 


\section{REFERENCES}

Burnett, W. C. Kim, G. and Lane-Smith, D. A. (2001) Continuous monitor for assessment of ${ }^{222} \mathrm{Rn}$ in the coastal ocean. J. Radioanal. Nucl. Chem. 249, 167-172.

Burnett, W. C. and Dulaiova, H. (2003) Estimating the dynamics of groundwater input into the coastal zone via continuous radon-222 measurements. J. Environ. Radioact. 69, 21-35.

Burnett, W. C. et al. (2006) Quantifying submarine groundwater discharge in the coastal zone via multiple methods. Sci. Total Environ. 367, 498-543.

Church, T. M. (1996) An underground route for the water cycle. Nature 380, 579-580.

Dimova, N. Burnett, W. C. and Lane-Smith, D. (2009) Improved automated analysis of Radon (222Rn) and Thoron (220Rn) in Natural Waters. Environ. Sci. Technol. 43, 8599-8603.

Dulaiova, H. et al. (2005) A multi-detector continuous monitor for assessment of Rn-222 in the coastal ocean. J. Radioanal. Nucl. Chem., 263, 361-365.

Kim, G. et al. (2003) Large submarine groundwater discharge (SGD) from a volcanic island. Geophy. Res. Lett., 30. doi:10.1029/2003GL018378.

Kim, G. et al. (2005) Submarine groundwater discharge (SGD) into the Yellow Sea revealed by ${ }^{228} \mathrm{Ra}$ and ${ }^{226} \mathrm{Ra}$ isotopes: implications for global silicate fluxes. Earth Planet. Sci. Lett. 237, 156-166.

Kim, G. Kim, J-S. and Hwang, D-W. (2011) Submarine groundwater discharge from oceanic islands standing in oligotrophic oceans: Implications for global biological production and organic carbon fluxes. Limnol. Oceanogr. 56, 673-682.

Kumar P., et al. (2012) The effect of tidal fluctuation on ground water quality in coastal aquifer of Saijo plain, Ehime prefecture, Japan. Desalinization, 286, 166-175.

Langevin, C. D., et al. (2007) SEAWAT Version 4: A Computer Program for Simulation of Multi-Species Solute and Heat Transport: U.S. Geological Survey Techniques and Methods Book 6, Chapter A22, $39 \mathrm{p}$

Moore, W. S. (1996) Large groundwater inputs to coastal waters revealed by 226Ra enrichments. Nature 380, 612-614.

Moore, W. S. (2010) The effect of submarine groundwater discharge on the ocean. Ann. Rev. Marine Sci. 2, 59-88.

Robinson, C., Li, L. and Barry D.A. (2006) Effect of tidal forcing on a subterranean estuary. Advances in Water Resources 30 , $851-865$

Taniguchi, M. et al. (2002) Investigation of submarine groundwater discharge. Hydrol. Processes 16, 2115-2129.

Taniguchi, M., Ishitobi, T. and Saeki, K. (2005) Evaluation of time-space distributions of submarine groundwater discharge, Ground Water 43, 336-342.

Taniguchi, M., et al. (2006a) Evaluations of spatial distribution of submarine groundwater discharge. Geophys. Res. Lett. 33, L06605, doi:10.1029/2005GL025288.

Taniguchi M. T. Ishitobi and J. Shimada (2006b) Dynamics of submarine groundwater discharge and freshwater-seawater interface: J. Geophys. Res. 111, C01008, doi:10.1029/2005JC002924. 